\title{
Lessen uit de voortplnting
}

Citation for published version (APA):

de Haan, J. (2006). Lessen uit de voortplnting. Maastricht University. https://doi.org/10.26481/spe.20061027jh

Document status and date:

Published: 27/10/2006

DOI:

10.26481/spe.20061027jh

Document Version:

Publisher's PDF, also known as Version of record

\section{Please check the document version of this publication:}

- A submitted manuscript is the version of the article upon submission and before peer-review. There can be important differences between the submitted version and the official published version of record.

People interested in the research are advised to contact the author for the final version of the publication, or visit the DOI to the publisher's website.

- The final author version and the galley proof are versions of the publication after peer review.

- The final published version features the final layout of the paper including the volume, issue and page numbers.

Link to publication

\footnotetext{
General rights rights.

- You may freely distribute the URL identifying the publication in the public portal. please follow below link for the End User Agreement:

www.umlib.nl/taverne-license

Take down policy

If you believe that this document breaches copyright please contact us at:

repository@maastrichtuniversity.nl

providing details and we will investigate your claim.
}

Copyright and moral rights for the publications made accessible in the public portal are retained by the authors and/or other copyright owners and it is a condition of accessing publications that users recognise and abide by the legal requirements associated with these

- Users may download and print one copy of any publication from the public portal for the purpose of private study or research.

- You may not further distribute the material or use it for any profit-making activity or commercial gain

If the publication is distributed under the terms of Article $25 \mathrm{fa}$ of the Dutch Copyright Act, indicated by the "Taverne" license above, 


\section{Lessen uit de voortplanting}

Afscheidscollege

Prof.Dr. J . de Haan, FRCOG

27 Oktober 2006

Universiteit Maastricht 
Meneer de Rector, meneer de Decaan Faculteit der Geneeskunde, leden van de Raad van Bestuur van het azM en voorts allen die met uw aanwezigheid blijk geven van uw belangstelling, dames en heren.

\section{Inleiding}

Het is op een dag als vandaag, waarop een afscheid nemende hoogleraar het laatste college geeft, nogal eens gebruikelijk dat door de afscheid nemende persoon wordt terug gekeken op de meer of minder succesvolle eigen carrière, of op de ontwikkelingen binnen het betrokken eigen vakgebied tijdens de vervulling van het ambt als hoogleraar.

Ook voor mij lag dat wellicht voor de hand en zou ook het gemakkelijkst zijn geweest. I mmers over mijn loopbaan als gynaecoloog en/of hoogleraar in Amsterdam, Nijmegen en Maastricht, met daarnaast nog Medisch Directeur van de Vroedvrouwenschool te Heerlen en later Kerkrade, en gevolgd door de functie van Wetenschappelijk Directeur van GROW, één van de vijf onderzoeksinstituten aan de Medische Faculteit in Maastricht, en met de beklede bestuurlijke nevenfuncties, zou ik u gemakkelijk drie kwartier bezig kunnen houden. Hierbij zouden zowel inhoudelijke aspecten en bestuurlijke ervaringen, 
alsmede politieke overwegingen u wellicht in meer of mindere mate kunnen boeien.

Immers het gebeurt niet zo vaak dat een gynaecoloog tot waarnemend hoofd van de afdeling Hartchirurgie van een academisch ziekenhuis wordt benoemd, om maar eens één bijzonder aspect van mijn carrière er uit te lichten, hetgeen mij in 1996 overkwam.

Neen, deze weg zal ik vandaag niet met $\mathrm{u}$ inslaan en ik zal dus niet alleen terugkijken, maar het oog richten op de toekomst, gebruik makend van het verleden en u proberen duidelijk te maken wat mij heeft bewogen.

Het Leitmotiv van dit afscheidscollege is de voortplanting, zijnde het hoofdbestanddeel van mijn activiteiten met het accent op onderzoek.

\section{Het ambt van hoogleraar}

Een ambt is een openbare betrekking waarin men door de overheid benoemd wordt. De benoeming tot hoogleraar was in het verleden een dergelijke functie, dat met dit toch wat beladen woord werd gekenmerkt. Om dit te onderstrepen werden destijds dergelijke benoemingen aan de 
Rijksuniversiteiten in Nederland officieel door de Koningin bekrachtigd hetgeen ook bij mijn benoeming in Maastricht geschiedde.

Bij de aanvaarding van het ambt van hoogleraar in een klinisch vakgebied bestaat de leeropdracht uit drie onderdelen: onderwijs en onderzoek (bij wet gesteld onder verantwoordelijkheid van de Faculteit der Geneeskunde) alsmede patiëntenzorg (onder verantwoordelijkheid van de Raad van Bestuur van het academisch ziekenhuis). Hiernaast wordt men geacht leiding te geven aan de afdeling, nieuwe ontwikkelingen te stimuleren en wanneer er nieuwbouw plaatsvindt, zoals in Maastricht het geval was, eveneens de bouw en inrichting van de afdeling en het ziekenhuis (mede) te bepalen en te begeleiden, dit alles nog afgezien van noodzakelijke locale, nationale en/of internationale bestuurlijke activiteiten.

Tijdens mijn studie geneeskunde en latere specialisatie in de Obstetrie en Gynaecologie aan de Vrije Universiteit te Amsterdam, was de hoogleraar de alles bepalende persoon binnen een vakgebied. Er was er veelal ook maar één van per vakgebied en zijn wil was wet. Bewust gebruik ik hier de mannelijke vorm, want vrouwen werden zelden of nooit 
(overeenkomstig het benoemingsbeleid binnen de orthodoxe protestantse kerken en zeker binnen de katholieke kerk) tot het ambt geroepen.

Deze situatie nu, is in de loop van de bijna 30 jaar dat ik hoogleraar ben, sterk veranderd zowel door bestuurlijke veranderingen aan de universiteiten maar meer nog, in de medische disciplines zeker, door de snelle veranderingen welke zich voordeden binnen de maatschappij in het algemeen en de medische disciplines in het bijzonder. Het bleek niet meer mogelijk voor één persoon een heel medisch vakgebied in alle facetten te overzien en hieraan tot in detail leiding te geven, en ook nog de ontwikkelingen binnen de verschillende deelgebieden te volgen.

Persoonlijk was het me snel duidelijk dat er een keuze gemaakt diende te worden uit de veelheid van mogelijke taken: de patiëntenzorg om voldoende voeling met de praktijk te houden, het onderzoek om én in het vakgebied bij te blijven én het verder te ontwikkelen en (wellicht het belangrijkste) daadwerkelijk de afdeling te leiden. Dit laatste aspect was en is naar mijn mening wel het belangrijkste onderdeel van de werkzaamheden geweest: namens de afdeling voorop gaan in 
de voortdurende competitie locaal (zowel facultair als in het ziekenhuis) om personeel, middelen en ruimtes te krijgen en nationaal met betrekking tot de specialistenopleiding en het verwerven van financiering voor onderzoeksprojecten. I eder moment van verslapping in aandacht omtrent deze aspecten kon en kan nog steeds een afdeling jaren terugzetten in ontwikkeling.

Het op adequate wijze leiden van de afdeling, ook ik kan er vandaag niet omheen, werd en wordt echter in toenemende mate bemoeilijkt door de positie welke het management in de ziekenhuizen heeft gekregen hetgeen in niet geringe mate ten detrimente van de kwaliteit van de gezondheidszorg gaat. Mede ten gevolge van de inmiddels binnen de gezondheidszorg geïntroduceerde marktwerking meent men een ziekenhuis te moeten en te kunnen leiden als een productiebedrijf, waarbij volstrekt voorbij gegaan wordt aan het feit dat patiënten voor de dokter komen en rekenen op barmhartigheid, medeleven, tijd en een menselijke benadering. Deze aspecten worden momenteel (toenemend) ondergeschikt gemaakt aan productiecijfers, streefgetallen, logistiek en doorlooptijd en zelfs, zoals in Maastricht, productie operatiekamers. 
Professor dr. Jaap van Duyn, voormalig topman van Robeco, zegt het op deze manier, en ik citeer: "Onze economie wordt steeds zwaarder belast met mensen die anderen aan het werk zetten (of ervan afhouden), die administreren, registreren, motiveren, reorganiseren, adviseren, targets vaststellen, cursussen bedenken, processen begeleiden, beleidsnota's schrijven en elkaar bezighouden".

En dan gaat hij verder "De professional, de vakman, de uitvoerende heeft het in Nederland verloren van de manager. De manager, die over alles kan meepraten, maar nergens iets van weet". Einde citaat.

In dit verband is ook zeer lezenswaardig het artikel in dagblad Trouw van 20-09-2006 van professor Paul de Beer: hij schrijft, en ik citeer wederom "In veel organisaties en bedrijven geldt: hoe meer je vergadert en hoe meer nota's je schrijft, des te hoger wordt je gewaardeerd"

Zelf heb ik deze ontwikkeling meermalen omschreven als "het hoeft niet beter te zijn als het maar anders heet of anders georganiseerd wordt"

Meermalen heb ik me gevoeld zoals Herbert hier in de werkput, omringd door managers die zonder het door Herbert 
uitgevoerde werk en aangeleverde getallen en gegevens niets kunnen uitrichten. Onthullend in dit verband waren de recent (mei 2006) door het CBS gepubliceerde getallen met betrekking tot de toename van personeel in algemene ziekenhuizen: het percentage functies welke niet direct gerelateerd is aan de patiëntenzorg is tweemaal zo sterk toegenomen dan de functies direct betrokken bij de patiëntenzorg. Cursussen voor managers in de gezondheidszorg, zoals in Tilburg, floreren dan ook als nooit tevoren. Nog nooit hebben zich zoveel mensen met de patiëntenzorg bemoeid zonder daadwerkelijk verstand van zieke mensen te hebben, laat staan ooit persoonlijk gezorgd te hebben voor een patiënt of direct daarvoor verantwoordelijk te zijn geweest.

Hoewel vrijwel iedere afscheid nemende hoogleraar dit probleem bespreekt in de afscheidsrede, gebeurt aan deze hoogst ongewenste situatie weinig tot niets en ik vraag me af wie er nog in staat en/of bereid is daarin daadwerkelijk het mes te zetten. Daarvoor zal tenminste de filosofie dat de geneeskunde geheel bedrijfsmatig kan worden uitgeoefend en dus een ziekenhuis geleid kan worden als een autofabriek of zoals de vroegere PTT, drastisch moeten worden bijgesteld. 
Helaas hebben de artsen en hun beroepsorganisaties zitten slapen toen deze ontwikkelingen zich voordeden.

Daarbij diende zich de laatste jaren een zo mogelijk nog bedreigender situatie aan voor het up to date en het in stand houden van een afdeling, en wel het als leidinggevende van een afdeling manager worden in het management echelon één niveau hoger dan de afdeling zelf. Er zijn maar weinig mensen die de verantwoordelijkheid, welke het conflict van plichten dat die situatie met zich meebrengt binnen de inmiddels ontstane bedrijfsmatige filosofie bij bijvoorbeeld bezuinigingsrondes, verdeling van ruimtes, menskracht of apparatuur, adequaat kunnen hanteren.

Immers, kiest men voor het centrale beleid en voldoet daarmee aan de gestelde targets, of laat men het belang van de patiënt en eigen afdeling prevaleren waarbij de door centraal gestelde targets niet worden gehaald.

Toen de vorige Raad van Bestuur mij dan ook verzocht in het azM een Behandel- en Zorgeenheid te leiden, waarvan de afdeling Obstetrie en Gynaecologie deel uitmaakte, heb ik dat verzoek resoluut afgewezen. 
Overigens leidde deze afwijzing wel tot een ontwikkeling in mijn carrière, op een terrein van het ambt van hoogleraar dat door mij als zeer belangrijk werd geacht, en wel het onderzoek.

Mijn leermeesters Janssens, Stolte en Eskes hebben mij reeds zeer vroeg in mijn opleiding gewezen op het belang van het wetenschappelijk onderzoek voor de ontwikkeling en het in stand houden van een academische afdeling, de ontwikkeling van het vakgebied zelf en het onderwijs, in de breedste zin van de betekenis.

Immers, onderzoek heeft of kan in de toekomst belangrijke consequenties hebben voor én het klinisch handelen én het onderwijs, maar tevens in vergaande mate de positie van een afdeling in het universitaire bestel, locaal, nationaal dan wel internationaal bepalen. Onderzoek heeft dan ook altijd de volle aandacht gekregen, dit echter nadat eerst eind jaren zeventig de patiëntenzorg in Maastricht op academisch niveau was gebracht.

Een tweede verzoek van de toenmalige voorzitter van de Raad van Bestuur van het azM (Carpay) en de toenmalige Decaan van de Faculteit der Geneeskunde (Bonke) nu om leiding te gaan geven aan een nieuw op te richten onderzoeks- 
instituut, teneinde tot een evenwichtiger onderzoeksprogramma te komen binnen de medisch faculteit en het academisch ziekenhuis kon ik dan ook niet weigeren. Hoewel mijn eis om als gynaecoloog te kunnen blijven werken bijna nog roet in het eten gooide.

Dit leidde tot de tweede stap van de carrière in Maastricht : Wetenschappelijk Directeur van het Onderzoeksinstituut voor Groei en Ontwikkeling (GROW)

\section{I I. Het onderzoek}

Waarom maakt onderzoek deel uit van de leeropdracht van een hoogleraar? Wel één der taken van de Universiteit is, naast het geven van onderwijs, onderzoek doen. Onderzoek is namelijk van groot belang voor de ontwikkelingen binnen de verschillende vakgebieden, en dus voor de ontwikkelingen in de maatschappij. Het heeft en hoort daarnaast direct grote invloed te hebben op de inhoud en dus de kwaliteit van het onderwijs op alle niveau's: onderwijs aan studenten, aan promovendi, of op het postacademisch onderwijs.

Nu bestaan er verschillende vormen van onderzoek. Zelf voel ik me het meest aangetrokken (zeker de laatste zeven jaar van 
mijn carrière) tot basaal grensverleggend onderzoek dat gevolgen heeft voor de behandeling van patiënten en voortgezet wordt in klinisch wetenschappelijk onderzoek zodat het naadloos overgaat in translationeel onderzoek.

Gedurende de tijd, en dat is vanaf 1968, dat ik werkzaam was binnen de Obstetrie en Gynaecologie (de Voortplanting is mijns inziens een betere benaming) deden zich twee drama's voor:

1. het Softenon drama waarbij door het gebruik van dit middel tijdens de zwangerschap ernstige aangeboren afwijkingen bij de kinderen ontstonden.

2. het diethylstilboestrol drama, beter bekend als het DES drama, waarbij door het gebruik van dit middel in de zwangerschap, later in het leven kwaadaardige afwijkingen en aangeboren afwijkingen ontstonden bij de uit deze moeders geboren kinderen.

Aan de hand van dit DES drama, waar we heden ten dage nog altijd de gevolgen van zien op het spreekuur wil ik u illustreren hoe belangrijk onderzoek is voor de maatschappij in het algemeen, en de geneeskunde in het bijzonder. 
Aanleiding om juist het DES drama vandaag als voorbeeld te nemen, is het meisje van 16 jaar dat kort na mijn benoeming in Maastricht in 1978, hevig vaginaal bloedend werd ingestuurd naar het oude St. Annadal ziekenhuis. De werkdiagnose was aanvankelijk onvolledige miskraam en ze werd naar de operatiekamer gebracht voor het leeg maken van de baarmoeder. Toen werd onder narcose de diagnose snel duidelijk: kwaadaardige tumor van de vagina hetgeen werd bevestigd door microscopisch onderzoek: clear cell carcinoom. Wat is nu de oorzaak van en de aanleiding tot een dergelijke, in principe levensbedreigende, ziekte bij een zestien jarig meisje.

Een belangrijk probleem bij de voortplanting van de mens is de herhaalde miskraam. Een groot deel (10-15\%) van de klinisch vastgestelde zwangerschappen en zelfs $50 \%$ van alle laboratorium technisch vastgestelde zwangerschappen komt voortijdig tot een einde, soms enkele malen achtereen bij dezelfde vrouw.

Hiervoor was en is nog altijd niet immer een oorzaak te vinden en vele vormen van therapie werden geprobeerd, zonder dat er vooraf een deugdelijke hypothese was opgesteld of onderzoek was verricht naar het mogelijke effect van de veronderstelde 
therapie, noch naar de eventuele bijwerkingen van die therapieën was gekeken.

Zo kon het gebeuren dat er vanaf 1948 de Smith en Smith kuur werd geïntroduceerd. Deze bestond uit het in oplopende dosering toedienen van DES (een synthetisch oestrogeen dat gemakkelijk de placenta passeert) aan zwangere vrouwen met mislukte zwangerschappen in de voorgeschiedenis: herhaalde miskramen, dreigende vroeggeboorten, na een doodgeboren kind.

Ook in Nederland kreeg deze vorm van therapie veel aanhangers en werd DES zeker tot in 1975 voorgeschreven. De gevolgen van deze medicatie tijdens de zwangerschap waren wereldwijd enorm, zo bleek pas na jaren:

Bij kinderen geboren uit moeders die met DES waren behandeld traden obstetrische en fertiliteitsproblemen op, ontwikkelden zich kwaadaardige afwijkingen o.a. van vagina en baarmoeder en hadden de behandelde a.s. moeders meer kans op het later in hun leven ontwikkelen van borstkanker.

De omvang van dit probleem was en is ook in Nederland groot: het geschatte aantal met DES behandelde vrouwen bedroeg 
$180.000-360.000$ en dus het aantal betrokkenen (moeders, dochters en zonen) $360.000-720.000$.

Het aantal DES dochters ligt ergens tussen de 90.000 en 190.000 vrouwen.

Het middel was en is nog steeds verantwoordelijk voor een groot aantal afwijkingen:

- premaligne en maligne afwijkingen van de schede en de baarmoedermond bij meisjes, ernstige vormafwijkingen van de baarmoeder (onvruchtbaarheid en/of vroeggeboorte of miskramen veroorzakend.

- Genitale afwijkingen bij de uit deze zwangerschappen geboren jongens.

- De moeders bleken later een verhoogde kans op borstkanker te hebben.

- Momenteel wordt er onderzoek gedaan naar eventuele gevolgen in de $3^{\mathrm{e}}$ generatie: eierstokkanker lijkt bij muizen in de $3^{\mathrm{e}}$ generatie meer voor te komen en bij de mens lijkt het zo te zijn dat bij jongens zich meer hypospadie voordoet (plasbuis mondt niet uit op de top van de penis maar ver daaronder). 
De vraag die naar ik hoop bij $u$ op de lippen ligt is natuurlijk "Hoe kon dit nu zo verschrikkelijk misgaan". Laten we dit eens analyseren.

Kernspelers in dit drama zijn de volgende personen:

- $\quad$ Dodds et al. ontwikkelde in 1938 een synthetische stof met sterke oestrogene activiteit, het latere DES.

- $\quad$ Smith en Smith voerden in 1948 op onterechte gronden (ik kom daar straks op terug) de behandeling met DES in.

- Dieckmann et al. ( $h i j$ is de eerste voorzitter van de SGI (Society for Gynecologic Investigation) publiceerde in 1953 dat DES niet werkte.

In de discussie welke ontstond nadat Smith en Smith hun kuur met DES tijdens de $72^{\mathrm{e}}$ vergadering van de American Gynecological Society in 1949 in Hot Springs presenteerde, stelde Dieckmann reeds het gebruik van een placebo bij dit soort studies als zeer belangrijk te beschouwen. Hij beloofde hier zelf onderzoek naar te doen

- $\quad$ Gass et al. publiceerde in 1964 een artikel waaruit bleek dat bij muizen die in het voedsel een bepaalde hoeveelheid DES kregen, er meer borstkanker voorkwam. 
- $\quad$ Herbst et al. tenslotte publiceerde in 1971 onderzoeksresultaten welke het verband tussen DES en het clear cell carcinoom bij jonge vrouwen aantonen (zoals bij de 16 jarige patiënte zojuist gepresenteerd).

Het proces van onderzoek naar bijvoorbeeld een afwijking als herhaalde miskramen en de daaruit voortkomende resultaten laat zich benaderen en analyseren met behulp van een Deming circle (Plan - Do - Check - Act):

Eerst wordt een bepaalde ziekte gedefinieerd, vervolgens wordt getracht de basale mechanismen te ontrafelen waardoor deze ziekte ontstaat. Daarvoor is basale research nodig dat binnen verschillende velden van onderzoek kan plaatsvinden veelal ook in dierexperimenten.

Daaruit kan een potentiële behandeling van de ziekte en/of een diagnostische test voor de ziekte voortkomen. Een dergelijke behandeling wordt dan toegepast bij een groep patiënten met de ziekte welke onderzocht wordt, en de resultaten daarvan weer gebruikt om in de klinische zorg te implementeren etc. etc. 
Smith en Smith maakten met de introductie van DES een aantal klassieke fouten:

1. De ziekte waarvoor DES werd aangewend werd niet éénduidig gedefinieerd. Neen, het was nog erger: er werden 632 patiënten met tenminste drie totaal van elkaar verschillende ziektebeelden behandeld met DES: abortus, vroeggeboorte, dood kind in de voorgeschiedenis.

2. Er werd niet eens een poging gedaan om het basale ziektemechanisme te analyseren: op grond van een verhoogde uitscheiding van hormoon afbraakproducten (pregnanediol) in de urine van behandelde konijnen en vrouwen nam men aan dat de doorbloeding van de baarmoeder en de placenta door het toedienen van DES verbeterde en dus de zwangerschapsresultaten bij de verschillende ziektebeelden.

3. De resultaten van de behandeling met DES werden niet vergeleken in een controlegroep met dezelfde ziektebeelden zonder behandeling met DES en/of een placebo.

Dieckmann wees hierop reeds bij de eerste presentatie van Smith en Smith in 1949! (in Nederland tot en met 1975 voorgeschreven) 
4. Smith en Smith vergeleken hun resultaten van de DES behandeling met gegevens uit de literatuur en resultaten bij patiënten uit hun eigen kliniek in het verleden. Dat is echter hachelijk indien de ziektebeelden vooraf niet goed gedefinieerd worden.

5. Het effect van "tender love and care" werd geheel over het hoofd gezien.

Naast de fouten gemaakt door Smith en Smith zijn er nog een aantal opmerkelijke andere aspecten:

* Zoals Dieckmann reeds beloofd had in 1949 voerde hij wel placebo gecontroleerd onderzoek met DES uit en publiceerde dat in 1953 in de Am. Journal of Obstetrics and Gynecology: DES heeft niet het beoogde effect was zijn conclusie. (Veel later werd dit nog eens bevestigd in een Cochrane analyse in 2006). Hoewel het voorschrijven van DES iets afnam bleef het gebruik van DES groot, ook in Nederland, tot zeker in 1975.

* Ondanks de gepubliceerde feiten van Gass et al. in 1964 omtrent het ontstaan van borstkanker bij muizen behandeld 
met DES, bleef men het middel voorschrijven. In Nederland tot 1975.

* Pas toen in 1971 door Herbst et al. de samenhang werd aangetoond tussen het ontstaan van clear cell carcinoom van de vagina bij jonge vrouwen en het in de baarmoeder blootgesteld geweest zijn aan DES, daalde het gebruik van deze medicatie bij zwangeren sterk, maar het werd helaas in Nederland tot zeker in 1975 nog incidenteel voorgeschreven.

Welke lering kan er nu getrokken worden uit dit drama in de Geneeskunde waarvan de gevolgen nu nog dagelijks op het spreekuur worden gezien:

1. Met het voorschrijven van geneesmiddelen moet uiterste voorzichtigheid in acht worden genomen, zeker bij vrouwen in de $2^{\mathrm{e}}$ helft van de menstruele cyclus en tijdens de zwangerschap.

2. Veronderstelde werking van geneesmiddelen behoort getoetst te worden in basale research modellen (inclusief dierexperimenteel onderzoek tot in enkele generaties) en daarna in goed opgezet klinisch onderzoek. 
3. Van iedere behandeling, ook medicamenteus, behoort deugdelijke verslaglegging plaats te vinden ook omtrent de aard van het middel en de dosering. Tevens horen ziektegeschiedenissen langdurig bewaard te blijven, in ieder geval langer dan de nu recent ingevoerde gangbare termijn van 10 jaar. Toen immers potentiële slachtoffers van het DES drama (terecht) wilden weten of ze het middel inderdaad hadden gekregen, bleek hoe fragmentarisch de verslaglegging was, indien die er al was.

4. Er hoort een register van bijwerking te zijn alsmede een register van aangeboren afwijkingen zodat eventuele calamiteiten snel aan het licht komen.

5. Een wellicht nog belangrijker aspect is dat tijdens de studie geneeskunde, maar ook daarna, artsen getraind moeten worden in methoden van onderzoek, in literatuurstudie en (tegenwoordig) wetenschappelijke zoekprogramma's. Men moet er van doordrongen worden dat slechts door een voortdurend proces van bij- en nascholing en literatuur studie de kans op dergelijke calamiteiten zo klein mogelijk gehouden worden. Dit stelt uiteraard eisen aan de studie geneeskunde en aan de opleiding tot specialist: er dient 
voldoende ruimte en aandacht te zijn voor training in wetenschappelijk onderzoek en wetenschappelijke stages in binnen- en buitenland. Het is én de verantwoordelijkheid van de medische faculteiten in Nederland én de MSRC, dat de opleiding tot arts en/of specialist nimmer verwordt tot een beroepsopleiding.

6. Een belangrijke algemene les die reeds toen (in 1971) geleerd kon worden was en is, dat de kiem van bepaalde ziekten, welke ontstaan op latere leeftijd, reeds gelegd kan worden tijdens het verblijf in de baarmoeder. (Het is momenteel sinds het werk van Barker uit Southampton bijna gemeengoed geworden: diabetes mellitus, hart en vaatziekten, osteoporosis). Dit feit stelt hoge eisen én aan de wijze waarop zwangeren in de maatschappij moeten worden beschermd én de wijze van vastleggen en bewaren van medische gegevens. Ik wil dit wederom illustreren aan de hand van de DES problematiek en de uit deze zwangerschappen geboren meisjes.

Zoals eerder vermeld zijn geschat alleen reeds in Nederland 190.000 - 380.000 vrouwen blootgesteld aan DES. 
Dankzij het centrale registratiesysteem van de afdelingen Pathologie in Nederland (PALGA genaamd) kan vanaf 1988 vrij nauwkeurig het aantal vrouwen geïnventariseerd worden, geboren na 1947 dat een clear cell carcinoom van de vagina of baarmoedermond ontwikkelt en door navraag te doen bij de behandelende artsen van de moeders destijds, of er sprake is geweest van behandeling met DES tijdens de betreffende zwangerschap.

Analyse van de leeftijden bij alle patiënten, geboren na 1988, waarop een clear cell carcinoom ontstaat, levert een opvallende verdeling op. Er blijkt sprake te zijn van twee verschillende populaties: bij de eerste groep ontstaat de maligniteit op een gemiddelde leeftijd van 26 jaar ( 17 - 37 jaar) en in de andere groep ontstaat het carcinoom op een gemiddelde leeftijd van 72 jaar (44 - 88 jaar), geboren vóór 1947 en niet aan DES blootgesteld (Hanselaar et al. 1997).

In de eerste jonge groep zitten overigens alle DES dochters die in Nederland na 1988 zijn gediagnostiseerd met een clear cell carcinoom.

Kijken we nu naar de groep vrouwen welke een clear cell carcinoom hebben ontwikkeld zonder aan DES te zijn 
blootgesteld dan is ook in deze groep een opvallende leeftijdsverdeling te zien: een jonge groep en een veel oudere groep (Hanselaar et al. 1997).

Dit levert interessante veronderstellingen op omtrent de (secundaire?) oorzaken van het ontstaan van deze maligniteit: is het de hormonale stimulatie welke tot stand komt vanaf de menarche en/of juist het wegvallen daarvan na het intreden van de menopauze welke het proces van kwaadaardige ontaarding in gang zet?

Indien dat laatste ook geldt voor de populatie DES dochters welke nog geen maligniteit op jonge leeftijd hebben ontwikkeld, dan moet theoretische gerekend worden met nog een probleem ten gevolge van DES op veel oudere leeftijd.

Dit onderstreept eens temeer hoe lang en ingrijpend onoordeelkundig handelen kan strekken doordat er vooraf geen deugdelijk basaal en vervolgens evenmin deugdelijk klinisch wetenschappelijk onderzoek heeft plaatsgevonden. Hier geldt met recht de stelling: "If you think research is expensive, just try disease". 


\section{Enkele aspecten van klinisch wetenschappelijk \\ onderzoek}

Het belang van onderzoek in het algemeen zal u naar ik aanneem nu wel duidelijk zijn. Echter het klinisch wetenschappelijk onderzoek kent een aantal facetten welke apart aandacht vragen. Wat is nu klinisch wetenschappelijk onderzoek? Bally et al. definieerde het in 1987 als volgt: “patiënt gebonden onderzoek is medisch wetenschappelijk onderzoek dat zich richt op vraagstellingen welke vanuit ziek zijn worden gegenereerd en dat plaatsvindt in de kliniek of polikliniek, ongeacht of het gericht is op preventie, cure of care. Gezien de plaats van het onderzoek (kliniek of polikliniek) is het noodzakelijk dat klinisch wetenschappelijk onderzoek wordt verricht door artsen, assistenten geneeskundigen in opleiding of medisch specialisten. Afhankelijk van de aard van het onderzoek zal dit type onderzoek plaatsvinden aan patiënten of aan biologisch materiaal dat van patiënten wordt verkregen" Deze definitie overziende kan dat onderzoek zijn naar het effect van medicijnen, nieuwe laboratoriumtesten, nieuwe operatieve procedures, het effect van hulpmiddelen enz. enz. 
Gezien de rol welke patiënten spelen in dit type onderzoek vereist het niet alleen een correcte en onafhankelijke onderzoeksopzet, maar ook dient dergelijk onderzoek volstrekt verantwoord te zijn en opgezet te worden volgens de regels van "good clinical practice". Het opzetten en uitvoeren van dergelijk onderzoek moet geleerd worden en studenten en artsen horen (ik zei het reeds eerder), daarin reeds tijdens hun opleiding in getraind te worden. Een dergelijke training vereist overigens iets anders dan het testen van medicamenten voor de farmaceutische industrie (met de daarbij behorende revenuen) of onderzoek uitgezet ("geseed") door de farmaceutische industrie zonder eigen, vanuit de kliniek ontwikkelde, vraagstellingen.

Nog twijfelachtiger wordt het wanneer onderzoek primair wordt geïnitieerd om eventuele winst te genereren teneinde of tekorten in de organisatie weg te werken of anderszins voor de organisatie onbereikbare doelen te realiseren. Dus geen onderzoek primair om het financiële gewin.

Klinisch en wetenschappelijk onderzoek in een academisch ziekenhuis hoort translationeel te zijn: dit betekent dat het zoveel mogelijk moet passen in de bestaande basale 
onderzoekslijnen en een voortzetting moet zijn van het basale wetenschappelijke onderzoek, maar nu in de kliniek. De neiging of zelfs het streven om een productielijn onderzoek, met dienovereenkomstig winstoogmerk, op te zetten gaat volstrekt voorbij aan het wezen van een academische setting: werken aan de "cutting edge" van het vakgebied in kwestie. De toenemende ongewenste afhankelijkheid van de onderzoeker van de (farmaceutische) industrie wordt helaas gestimuleerd doordat er van overheidswege steeds minder geld beschikbaar wordt gesteld voor onderzoek. De zogenoemde "eerste geldstroom", geld beschikbaar gesteld voor onderzoek door de overheid en/of publieke sector is praktisch opgedroogd in Nederland. Dit dwingt onderzoekers in de richting van de industrie die vrijwel geen geld beschikbaar stellen voor onafhankelijke klinische trials. Echter klinisch wetenschappelijk onderzoek hoort niet te koop te zijn. In dit verband is het editorial uit 2000 in het New England J ournal of Medicine, getiteld "Is academic medicine for sale?" zeer lezenswaardig voor alle leiding gevenden in de academische gezondheidszorg. 


\section{Waarom Onderzoeksinstituut GROW (Groei en Ontwikkeling}

Het onderzoek binnen de Medische Faculteit van de Universiteit van Maastricht is van oudsher georganiseerd in onderzoeksinstituten, gefinancierd door faculteit en in mindere mate door het academisch ziekenhuis. Dergelijke instituten worden geleid door een Wetenschappelijk Directeur (verantwoordelijke voor de wetenschappelijke inhoud van het onderzoeksprogramma), een beheerder en een secretariaat. Vakgroepen en afdelingen brengen onderzoekscapaciteit in deze onderzoeksinstituten. Het onderzoeksprogramma is over verschillende divisies binnen zo'n instituut verdeeld. De divisieleiders sturen het onderzoek aan binnen een divisie.

Eind jaren negentig kwam het besef bij de Raad van bestuur van het azM en het Bestuur van de Medische Faculteit, dat het niet goed mogelijk was een academisch ziekenhuis (dus met onderzoek en onderwijs) in stand te houden met alleen aandacht voor onderzoek in hart en Vaatziekten en Neurologische/Psychiatrische ziektebeelden. Immers dit zou leiden tot het verwaarlozen van (gezien de samenhang tussen onderzoek enerzijds en onderwijs en patiëntenzorg anderzijds) 
belangrijke velden van patiëntenzorg zoals de oncologie en de ontwikkelingsbiologie. Bovendien zaten en zitten er binnen deze gebieden nog steeds de meeste art. 18 (intussen artikel 2) voorzieningen. Dit zijn ziekenhuisvoorzieningen die door de overheid apart extra gefinancierd worden zoals beenmergtransplantatie, IVF, PGD, NICU, genetische diagnostiek, geavanceerde ultrageluidsdiagnostiek etc. etc. Dergelijke voorzieningen blijven alleen in stand en op niveau indien er binnen deze gebieden ook grensverleggend onderzoek plaatsvindt.

Dientengevolge werd in 1999 het Onderzoeksinstituut Groei en Ontwikkeling (GROW) opgericht door een gezamenlijke actie van het azM en de Medische Faculteit. Zelf werd ik benoemd tot Wetenschappelijk Directeur. Deze benoeming had enige voeten in de aarde daar ik bleef vasthouden aan de voorwaarde om deeltijds klinisch te blijven werken. Dit kwam voort uit het feit dat in een zich ontwikkelend academisch ziekenhuis, waarin over een breed veld geen traditie van onderzoek bestond, laat staan van klinisch onderzoek, een wetenschappelijke directeur midden in dat veld diende te staan. 
Ook was er op die manier altijd een terugkeer in de kliniek mogelijk, mocht het onderzoeksinstituut mislukken.

Er werd gestart met drie divisies, later teruggebracht naar twee: Ontwikkelingsbiologie en Oncologie.

Het wetenschappelijk programma werd gebaseerd op het idee (ontwikkeld in 1992 bij de voorbereiding van een lezing voor de Ned. Ver. voor Obstetrie en Gynaecologie over de behandeling van eierstokkanker) dat abnormale groei alleen dan goed doorgrond en behandeld kan worden, wanneer de normale groei begrepen werd. Zo kwam het mission statement van GROW tot stand, luidend:
“The profound study, teaching and translation into application of mechanisms underlying cell growth and tissue differentiation in physiological and pathological conditions including clinical consequences".

Sinds de start van GROW met dit mission statement, werd zowel vanuit de eigen organisatie als van buiten, de vraag gesteld wat het onderzoek in de divisie Perinatale Geneeskunde / Ontwikkelingsbiologie nu met het onderzoek in de 
divisie Oncologie gemeen had. Zoals reeds gezegd kwam de opzet van het researchprogramma van GROW voort uit de overtuiging dat abnormale groei niet te begrijpen is, laat staan te bestrijden zoals we graag willen bij kwaadaardige processen, wanneer de normale groei niet goed wordt begrepen. Daar u mogelijk van deze stellingname nog niet geheel overtuigd bent door het voorbeeld van de gevolgen van het voorschrijven van DES tijdens de zwangerschap, op de zwangere zelf en op de volgende generaties, wil ik u nog twee voorbeelden tonen die laten zien hoe nauw normale en abnormale groei met elkaar verweven zijn.

Het eerste voorbeeld is een zwangere die bij mij onder controle stond in Nijmegen begin jaren zeventig. Wij ontmoetten elkaar op het parkeerterrein voor de verloskunde kliniek: zij duidelijk met weeën en op weg naar de verloskamers, en ik op weg naar huis. We spraken af dat ik haar over ongeveer een uur zou zien. Twee uur later toen haar kind geboren werd, bleek dat er zich een tumor tijdens de zwangerschap in één der ogen had gevormd. Dit bleek een retinoblastoom te zijn (let wel, dit was nog voor de tijd dat er ultrageluidsdiagnostiek bestond). 
Teneinde te kunnen uitleggen hoe een dergelijke abnormale groei zich kon voordoen in de baarmoeder moet ik even met $u$ naar de basisprincipes van hoe levende organismen zich in stand houden en de celdeling.

Levende wezens blijven in stand door een delicaat evenwicht tussen celdeling en celdood (voorbeeld: huid verbrand in de zon, vervanging van darmbekleding).

Zodra dit evenwicht verstoord wordt, wordt het leven bedreigd, of door de groei van tumoren of door verlies van essentiële weefsels en structuren.

De normale celdeling is een complex proces, dat onder genetische controle staat en verloopt in een aantal stappen welke tijdelijk of permanent onderbroken kunnen worden. Binnen dit proces van de celdelingcylus zijn stimulerende en remmende factoren actief, welke genetisch bepaald zijn:

* proto-oncogenen (stimuleren groei).

Deze genen coderen voor eiwitten betrokken bij groeifactoren of bij signaaloverdracht in de celcyclus. De verandering van normale proto-oncogenen tot oncogenen kan het gevolg zijn van een aantal veranderingen in ons erfelijk materiaal (de genen): punt mutaties, translocaties etc.. 
Deze veranderingen kunnen resulteren in ontregeling van de celgroei en het ontstaan van een tumor.

* tumor suppressor genen: deze genen voorkomen normaliter ongebreidelde celgroei. Genetische veranderingen in deze genen (mutaties, translocaties etc) kunnen resulteren in ongecontroleerde celgroei.

Het ontstaan van een kwaadaardig proces kan dus veroorzaakt worden of door mutaties in een proto-oncogen of door het verlies van de activiteit van een tumor suppressor gen. Het eerste tumor suppressor gen dat werd ontdekt is het retinoblastoma gen 1 . Het eiwit dat in de normale situatie wordt geproduceerd door het retinoblastoma gen, remt in de celdelingscyclus de overgang van de G0 - G1 fase naar de Sfase. Wanneer dit gen dus niet goed werkt kan er zelfs reeds in de baarmoeder bij het kind een retinoblastoom ontstaan, zoals in het getoonde voorbeeld. Het gen blijkt echter ook een rol te spelen bij het ontstaan van longkanker, blaaskanker en een vorm van botkanker (osteosarcoom). 
(Voor de deskundigen onder $\mathrm{u}$ : bij het betrokken kind betrof het een niet erfelijke vorm van retinoblastoom, maar de sporadische vorm ervan).

Zo zijn er talloze voorbeelden te geven van paralellen tussen normale groei en abnormale groei, en is het ontstaan van GROW en het daarbij gekozen mission statement niet maar willekeurig.

Een meer basaal voorbeeld van een dergelijke parallel is de vasculogenese/angiogenese en de $\mathrm{O}_{2}$ voorziening van weefsels, een terrein waaraan binnen GROW volop wordt gewerkt, zowel binnen de divisie Ontwikkelingbiologie als de divisie Oncologie. Het proces van abnormale celdeling en het daardoor ontstaan van een tumor, bedreigt het leven op zich niet direct, daar de tumor in de meeste gevallen veilig kan worden verwijderd zonder al teveel schade in het lichaam aan te brengen. Echter het proces van invasie in de omringende weefsels en de uitzaaiingen (metastasen) is echter wel levensbedreigend. Dit proces verloopt in een aantal stappen:

1. Na expansieve groei van de primaire tumor die alle verdedigingsmechanismen van het lichaam heeft weten te omzeilen, bereikt de tumor de basale membraam. 
2. Productie van weefsel oplossende (hydrolytische) enzymen (of het aanzetten van gastheercellen tot deze productie) lost deze basaal membraan op (collagenase IV).

3. Het tumor omringende weefsel kan dan worden geinvadeerd waarschijnlijk gereguleerd door chemotaxis (integrinen).

4. Het bereiken en openen van bloed en lymfevaten, versleping via de circulatie, het vastlopen in dunne vaten en de invasie in andere weefsels, inclusief nieuwe bloedvatvoorziening, de angiogenese.

Angiogenese en tumor ingroei zijn nauw met elkaar verbonden: zo lang geen vaatingroei optreedt en er dus onvoldoende $\mathrm{O}_{2}$ beschikbaar komt limiteert het proces zich vanzelf. Dit resulteert bij normale tumor suppressor genen (vooral $P_{53}$ ) in spontane celdood (apoptosis). Echter cellen met insufficiente tumorsuppressor genen zijn min of meer resistent voor tekort aan zuurstof (hypoxie) of worden er zelfs door gestimuleerd. Deze feiten verbinden vaatingroei en $\mathrm{O}_{2}$ voorziening met de functie en veranderingen in de tumorsuppressor genen. 
Er blijken opmerkelijk genoeg grote overeenkomsten te bestaan tussen de wijze waarop een tumor in het omringende weefsel penetreert en de innestelling van het embryo in de baarmoeder.

Tijdens de vroege fase van de embryonale ontwikkeling ontstaan er twee groepen cellen: één groep waaruit de foetus ontstaat en een andere groep wordt trofoblast waaruit o.a. de placenta bestaat.

Dit placentaire deel is het enige deel van het embryo dat direct contact krijgt met de moederlijke cellen. Dan is het al geïmplanteerd in de baarmoeder wat bij de mens gebeurt aan het einde van de eerste zwangerschapsweek. Het embryo breekt de bekleding van het baarmoederslijmvlies af en penetreert in het onderliggende endometrium (stroma). Deze trofoblastcellen (placenta) banen zich een weg in de bekleding van de baarmoeder en tasten ook de op hun weg komende bloedvaten aan waardoor er een systeem van ruimten (sinusoïden) ontstaat gevuld met moederlijk bloed hetwelk de basis vormt van de moederlijke placentaire circulatie. Sommige delen van de trophoblastcellen groeien uit als vlokken en worden d.m.v. vaatnieuwvorming gevasculiseerd vanuit het 
embryo aldus de basis vormend van de latere foetale circulatie in de placenta.

Tenminste drie aspecten zijn nu in het kader van normale/ abnormale groei zeer boeiend:

- $\quad$ hoe komt het dat een deel van de trofoblastcellen zich agressief gedraagt en zich binnenvreten in het moederlijk weefsel als ware het een kwaadaardige tumor (soms verloopt dit proces ongeremd en leidt dan ook tot de ontwikkeling van een kwaadaardige tumor van de placenta of doorgroei door de baarmoederwand).

- $\quad$ waarom gedraagt zich een ander deel van de trofoblast zich niet agressief maar bekleedt netjes de uitgroeiende vlokken waarin de foetale circulatie groeit zodat er voor $\mathrm{O}_{2}$ uitwisseling tussen moeder en kind kan worden zorggedragen - $\quad$ hoe vindt de signalering tussen het zich ontwikkelende embryo en het moederlijke organisme plaats - $\quad$ op welke wijze vindt de vorming van bloedvaten in de vlokken plaats?

Welnu, zowel de groeiende tumor als het zich implanterende embryo maken beide van in grote mate vergelijkbare 
mechanismen gebruik om hun toch onderscheiden doel te bereiken: ook het embryo kleeft zich vast aan het moederlijke weefsel, doorbreekt de basaalmembraan en penetreert dieper in onderliggend weefsel, vormt nieuwe bloedvaten om de $\mathrm{O}_{2}$ voorziening op peil te houden etc. etc.

In beide situaties spelen dezelfde stoffen een rol om de sterk van elkaar verschillende doelen te bereiken.

Eens te meer laten deze voorbeelden zien hoe nauw normale en abnormale groei met elkaar verbonden zijn.

\section{Ontwikkelingen binnen GROW}

In hoeverre is nu het in 1999 geformuleerde uitgangspunt van GROW om een onderzoeksinstituut voor normale en abnormale groei te starten succesvol geweest. Naar mijn mening is dat een succes story geworden maar het eindoordeel laat ik graag aan u over.

GROW begon eind 1999. Na een externe visitatie in 2000 en focussering van het onderzoeksprogramma in 2004, werd de in 2005 aangevraagde KNAW erkenning als onderzoeksschool in 2006 verkregen. Dit op eigen kracht en vanuit Maastricht. 
De mankracht is in deze periode sterk toegenomen vooral in de categorieën promovendi en ondersteunend personeel.

Gemiddeld wordt er per jaar bijna $3,5 \times 10^{6} €$ aan externe subsidie verworven en inclusief 2005 is er in totaal bijna $€ 25 \times 10^{6}$ aan externe fondsen door GROW wetenschappers verworven.

Het aantal Wi-1 publicaties is meer dan verdubbeld (117 $\rightarrow 265$ ), met behoud en zelfs toename van de kwaliteit: bijna $60 \%$ van de publicaties bevindt zich in het eerste kwartiel van de tijdschriften van het betreffende wetenschapsgebied en gerangschikt naar impact factor.

Het aantal promoties stijgt eveneens gestaag.

Binnen de kaderprogramma's van de Europese Unie wordt sterk geparticipeerd, hetgeen in een groot wetenschappelijk netwerk in Europa voor GROW heeft geresulteerd

Toekomstige ontwikkelingen binnen GROW:

- opzetten van een research master "normale en abnormale groei"

- onderzoekers gaan trainen (c.q. doen trainen) voor klinisch onderzoek. Wil het UMC in Maastricht werkelijk een 
wereldspeler worden, zoals in alle toekomst scenario's staat, dan moeten arts-onderzoekers getraind worden voor klinisch onderzoek. Dat is iets anders dan intern cursussen voor good clinical practice aan te bieden voor $€ 250$,- per persoon. Hier rust een grote verantwoordelijkheid op de bestuurders voor scholing en bijscholing van specialisten tot klinische onderzoeker in gerenommeerde instituten in binnen- en buitenland. Dit teneinde in dit veld een reeds bestaande achterstand in het azM op te vangen en voor de toekomst voldoende kader op te kunnen bouwen om werkelijk translationeel klinisch wetenschappelijk onderzoek op academisch niveau te kunnen uitvoeren. 


\section{Dankwoord}

Gekomen aan het einde van dit afscheidscollege passen mij een aantal woorden van dank.

Dank aan mijn universitaire opleiders Janssens, Stolte en Eskes. Maar ook mijn niet universitaire opleider, mw. Kars, wiens zoon ik later mocht opleiden tot gynaecoloog. In het bijzonder dank en gedenk ik Co Greep, die mij naar Maastricht haalde.

I $\mathrm{k}$ dank de bestuurders van het azM (in het bijzonder Carpay) en de Universiteit Maastricht (Bonke, Vredevoogd en Dittrich) voor het in mij gestelde vertrouwen. Zeker toen het er op aan kwam om GROW verder uit te bouwen en zowel nationaal als internationaal op de kaart te zetten.

Ik dank tevens de beheerders van GROW (in het bijzonder Sebastiaan Huntjens) voor de hulp die ze hebben geboden bij het uitbouwen van GROW. Dit geldt eveneens voor de divisieleiders van GROW: Blanco, Evers, Geraedts, Lambin, Peeters en Ramaekers.

Velen hebben meegeholpen eind jaren zeventig, begin jaren tachtig een volwaardige academische afdeling Obstetrie en Gynaecologie op te bouwen in Maastricht en opleidings- 
bevoegdheid te krijgen. Mijn dank daarvoor aan zowel de toenmalige administratieve, verpleegkundige en medische staf.

Zoals deze ruiter langzaam het strijdtoneel verlaat zo zal ik ook in de toekomst mijn taken de één na de ander neerleggen. I $k$ wil $u$ echter nog één opdracht meegeven

\section{LET IT GROW}

Ik heb gezegd. 